Yayın Geliş Tarihi: $\quad 13.06 .2016$

Yayın Kabul Tarihi: 23.10.2016

Online Yayın Tarihi: 13.07.2017
Dokuz Eylül Üniversitesi İktisadi ve İdari Bilimler Fakültesi Dergisi

Cilt:32, Sayı:1, Yll:2017, ss. 243-269

\title{
En Çok ve En Az Kazandıran Meslekler Analizi: Türkiye Örneği
}

Meltem INCE YENILMEZ ${ }^{1}$

\section{Mehmet Hulusi DEMİ ${ }^{2}$}

$\ddot{O} z$

Ücret düzeyi, işgücü piyasasında yapılmış bir işin değerini objektif olarak ölçmek için kullanılan bir göstergedir. Ücret düzeyi ve davranışın her ülke ekonomisinde rolü tartışlmazdır. Bu makalede, Türkiye İstatistik Kurumu, Avrupa İstatistik Ofisi, Ekonomik Kalkınma ve İşbirliği Örgütünün sınıflandırmasına göre belirlenmiş en çok ve en az kazandıran mesleklerde 2010-2014 dönemine ait ücret dağllım eğilimleri ele alınmaktadır. Araştırmanın değişkeni, Türk Lirası (†) olarak ödenen aylık brüt ücrettir. Araştırmada yirmi dört ücret dağllımı incelenmiştir. Ücret düzeyinde farklllıklar ve iki mesleki grup arasında farklılaşma görülmüştür. Aylık brüt ücretin belirli bir çalışanın mesleğine bağımlılığının değerlendirilmesi araştırmanın ayrılmaz bir parçasını oluşturmaktadır.

Anahtar Kelimeler: En Çok Kazandıran Meslekler, En Az Kazandıran Meslekler, Aylık Brüt Ücret, Ücret Düzeyi, Ücret Değişkenliği, Ücret Dağılımı Gelişimi

JEL Sinıflandırma Kodları: D31, J30, J31.

\section{Analyzing the Best- and Worst-Paid Occupations: A Case of Turkey}

\begin{abstract}
The level of remuneration is indicative for the labour market in terms of an objective assessment of the value of work done. The wage level and behaviour play an indisputable role in the economy of every country. This paper deals with the 2011-2014 wage distribution trends of the best-paid and worst-paid occupations divided according to TUIKEUROSTAT-OECD classification. The three highest- and lowest-paid jobs from each occupational group are identified. Twenty-four wage distributions have been analysed. An integral part of the research is the assessment of the gross monthly wage dependence on a particular employee's occupation.
\end{abstract}

Keywords: Best-Paid Occupations, Worst-Paid Occupations, Gross Monthly Wage, Wage Level, Wage Variability, Wage Distribution Development.

JEL Classification Codes: D31, J30, J31.

${ }^{1}$ Doç.Dr., Yasar Universitesi, İktisadi ve İdari Bilimler Fakültesi, Ekonomi Bölümü, meltem.ince@yasar.edu.tr.

2 Prof. Dr., Yasar Üniversitesi, Meslek Yüksek Okulu, Yönetim Organizasyon, hulusi.demir@yasar.edu.tr. 


\section{M.İ. YENILMEZ- M.H.DEMIR}

\section{GİRIŞ}

Türkiye'de eğitim ve sağl1k sektörlerinde kazanç düzeyleri özellikle son zamanlarda çok tartışılan bir konu haline gelmiştir. Mesleki ücret ayrımcılığı üzerine olan bu araştırmanın hareket noktasını cinsiyet ve mesleğe göre sınıflandırılmış gruplar arasında gelir ve ücret farklılıklarının oluşturduğu temel sorunlar teşkil etmektedir. Bu makale küresel ekonomik durgunlukta meydana gelen değişikliklere odaklanarak 2011-2014 döneminde ücrette farklılaşma gelişimini ele almaktadır.

Türkiye'de ortalama (nominal) aylık brüt ücret, 1990 ve 2004 yılları arasında dört katından daha fazla artarak 414.000 TL'den 444.150.000 TL'ye çıkmıştır. 1 Ocak 2005 tarihinde para birimimizden altı sıfır silinip Yeni Türk Lirasının (YTL) tedavüle girdiği 2005 yılı ile 2015 yılı arasında ortalama (nominal) aylık brüt ücret neredeyse üç kat artarak 531 YTL'den 1,647 Ł'na yükselmiştir. (2012 yılı Mart ayında Türk Lirası [Ł] Yeni Türk Lirasının [YTL] yerine geçerek yeni bir Türk parası olarak tedavüle girmiştir) Bu makale sadece nominal aylık brüt ücrete atıfta bulunmaktadır. Türk ekonomisinin 1980'lerin ilk yarısında merkezi planlı ekonomiden piyasa ekonomisine kademeli geçişine belirli bir ücret artışı eşlik etmiştir. Enflasyonist baskıların önemli bir kaynağı olan ücret artışı, Türk lirası devalüasyonu, para biriminden 6 sıfırın silinmesi, fiyat liberalizasyonu, vergi reformu ve katma değer vergisi getirilmesi gibi diğer önemli faktörlerden farklı olarak 2001 yılına kadar kazanç büyütme katalizörü şeklinde davranan düşük işsizlik oranı ile uyarılmıştır. Sonraki dönemde ücret artış oranı ve işgücü verimliliği ters yönde büyümüştür. Ortalama (nominal) aylık brüt ücrette düşüş, 2009 y1lında global ekonomik krizin başlamasından hemen sonra, bir önceki yıla göre \% 1'den daha az bir azalma olarak kaydedilmiştir. Sonraki dönemde bu ücret yeniden 
yükselmeye başlamış ve 2015 yılına kadar büyüme hızı \% 4,4 (2013 yılı hızı) aşmamıştır. En çok ve en az kazandıran meslekler arasındaki farklar zamanla büyüdüğü sonucuna varılabilir. Beyin gücü gerektiren mesleklerde çalışanlar en yüksek ücret düzeylerine ulaşırken, fiziksel güç gerektiren meslekleri icra edenler daha düşük ücretler kazanmaktadır. Türkiye genelinde aylık ücretlerde en büyük farklılıklar yöneticiler arasında olup, en küçük farklılıklar ofis çalışanları ve eğitim kadrolarında kaydedilmiştir. 2015 yılında iş dünyası dışında sektörde ortalama gelir daha geniş olan iş dünyası sektöründe gelir ortalamasını biraz geçmiştir. Bu durumun iş dışı sektör çalışanların eğitim seviyesinin (\% 30 üniversite mezunu, her beşinci çalışan MYO mezunu) iş dünyası çalışanlarının eğitim seviyesinden (her yedinci çalışan üniversite mezunu, neredeyse yarısı MYO mezunu) daha yüksek olmasından kaynaklandığı düşünülmektedir. Genellikle, iş dünyası dışı sektörde maaşlar iş dünyasındaki çok daha değişken ücretlere göre daha kolay karşılaştırılabilir olmaktadır.

Belli ki, nüfusun aldığı ücretler ve gelir, araştırmacıların dünya çapında sürekli incelediği güncel bir konudur. Burada Türk ve yabancı bilim insanlarından sadece birkaçına değinelim: Tansel, Dalgıç ve Güven (2014) Türkiye'de ücret eşitsizliği ve ücret hareketliliği üzerine çalışmalar yürütmektedir. Cai Chen ve Zhou (2010) kentsel Çin'de gelir ve tüketim eşitsizliğini araştırmaktadır. Dagum (1997) gelir dağılımı modelleri ile ilgilenmektedir. Özcan, Üçdoğruk ve Özcan (2003) kentsel Türkiye'de cinsiyet, ücret ve serbest meslek ile ücret farklılıklarını incelemektedir. Baltagi, Baskaya ve Hülagü (2011) Hanehalkı İşgücü Anketinden bireysel verileri kullanarak Türk ücret eğrisini araştırmaktadır. Reiner (2012) Avrupa'da hanehalkı gelirlerinin eşitsizliğini ve hareketliliğini incelemektedir. Fields (2010) gelir hareketliliği ve uzun vadeli gelirler arasındaki korelasyonu incelemektedir. Battisti, Felbermayr, Peri ve 


\section{M.İ. YENILMEZ- M.H.DEMIR}

Poutvaara (2014) genel denge modeli kullanarak yerleşik nüfusun refah düzeyine göçün etkilerini incelemektedir. Evangelista de Carvalho Filho (2012) Brezilya'da çocuk işçiliğinin ve okullaşmanın bir belirleyicisi olarak hanehalkı gelirini araştırmaktadır. Fidrmuc ve Senaj (2014) ekonomik reformlar sırasında gelir, eğitim ve konut zenginliğini araştırmaktadır. Özer (2001) gelirin yanı sıra meslek ve eğitim gibi demografik özelliklerinde önemli faktörler olduğunu ve ücretler üzerinde etkisi olduğu için refah seviyesini arttırdığını tespit etmiştir. Hassan, Azali ve Lee (2014) yüksek gelirli ülkelerde Feldstein-Horioka Puzzle ve uluslararası sermaye hareketliliğini incelemektedir. Demir (2001) düşük teşvik, gizli işsizlik ve ücret dengesizliklerini incelemiştir. Ghosheh (2013) Afrika'da ücret koruma yasaları hakkında bir makale yayınlamıştır. Alaniz, Gindling ve Terrell (2011) Nikaragua'da asgari ücretin ücretlerin, iş ve yoksulluğun üzerindeki etkisini araştırmaktadır. Brucker ve Jahnk (2011) göçü, ücret tespitini ve işgücü piyasası etkilerini incelemektedir. Uyguç (2003) çalışmasında öğrencileri uygun mesleklere yönlendirmeyi, eğer iş hayatında ise işe uygun eleman seçmenin sonuçlarını araştırmıştır. Nordman ve Roubaud (2009) Madagaskar'da cinsiyet ayrımının oluşturduğu ücret farkını araştırmaktadır. Immervoll (2007) asgari ücret, asgari işçilik maliyetleri ve vergi işlemleri arasında ilişki kurmaktadır. Totty (2014) asgari ücretin istihdam üzerindeki etkisinin seçili sorunlarını incelemektedir. Hussmanns (2004;2005); Salem, Bensidoun ve Pelek (2011) Türk hanehalkının kayıt dışı ekonomide istihdam düzeyini ve hareketliliğini araştırmaktadır.

$\mathrm{Bu}$ nedenle, mevcut çalışmanın amacı, Türkiye'de ücret düzeyi farklılıkları ve en yüksek ve en düşük ücretli meslekler arasındaki farklılaşmayı tanımlamaktır. Bunun için 2010-2014 döneminde düzey özelliği gelişimi, değişkenlik ve aylık brüt ücret dağılımının konsantrasyonu ele alınmıştır. Bir diğer önemli amaç ise ekonomik krizde ve sonrasında 
Dokuz Eylül Üniversitesi İktisadi ve İdari Bilimler Fakültesi Dergisi Cilt:32, Sayl:1, Yll:2017, ss. 243-269

ücret dağılımında davranış farklılıklarını tespit ederek, en çok ve en az kazandıran meslekler arasında ücret dağılımında farklılıkları incelemektir. Makale aynı zamanda maksimum olabilirlik yöntemi ile teorik olasılık dağılımlarında farklı gelişmelerin analizini sunmaktadır. Örneklem dağılım şekillerini gösteren grafiklerin çizimi veri yapısından dolayı mümkün olmamıştır. Aylık brüt ücret ve belirli bir meslek arasında karşılıklı bağımlılığının araştırılması bu çalışmanın ayrılmaz bir parçasını oluşturmaktadır.

\section{VERI}

2010-2014 y1lları için araştırma verileri Türk İstatistik Kurumu (TÜİK) resmi web sitesinden elde edilmiştir. Onlar Ocak 2010 yılından bu yana yürürlükte olan meslek sınıflandırmasına göre gruplandırılmıştır. Durgunluğun ilk işaretleri 2009 yılının ilk yarısında belirgin olmasına rağmen, ücret gelişimini krizin başlangıcından itibaren tüm kriz süresince TÜİK metodolojisinde değişiklikler nedeniyle takip etmek mümkün olmamıştır. Önceki iş terminolojisi 2010 yılında TÜİK-EUROSTAT-OECD sınıflandırması ile değiştirilmiştir. Bu yüzden sürekli zaman serisi mevcut değildir. Aşağıda Tablo 1'de ve Şekiller 1-5'te, kullanılan önemli meslek gruplarının başlıkları ve kodları sunulmaktadır.

Tablo 1. Meslek Sinıflandirmaları

\begin{tabular}{|l|l|}
\hline 0 & Silahlı Kuvvetlerde Meslekler \\
\hline 1 & Yöneticiler \\
\hline 2 & Uzmanlar \\
\hline 3 & Teknik Elemanlar ve Uzman Yardımcıları \\
\hline 4 & Büro Destek Görevlileri \\
\hline 5 & Hizmet ve Satış Elemanları \\
\hline 6 & Vasıflı Tarım, Ormancılık ve Balıkçlık İşçileri \\
\hline 7 & El Sanatları ve İlgili İşlerde Çalışanlar \\
\hline 8 & Tesis ve Makine Operatörleri ve Montajcılar \\
\hline 9 & Nitelik Gerektirmeyen Meslekler \\
\hline
\end{tabular}




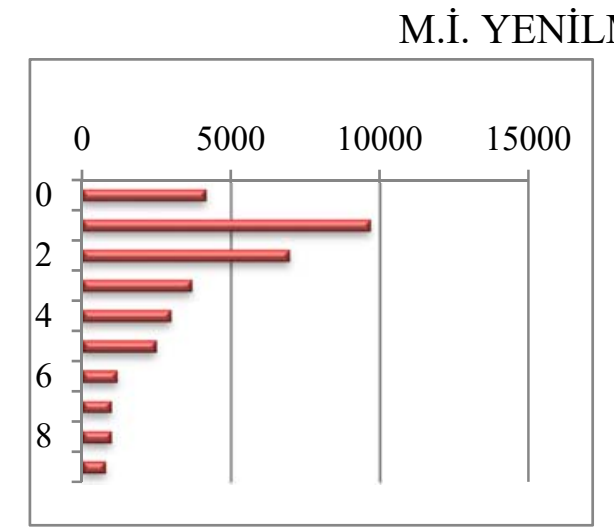

Şekil 1. 2010 Yılında Ortalama Aylık Brüt Ücrete Göre Meslek Sıralaması

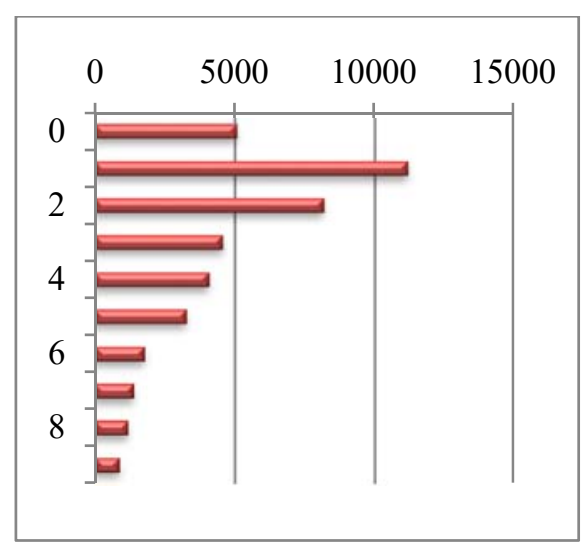

Şekil 3. 2012 Yılında Ortalama Aylık Brüt Ücrete Göre Meslek Siralaması

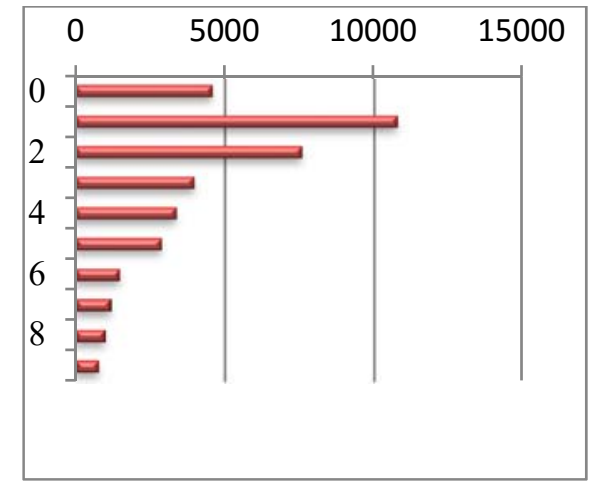

Şekil 2. 2011 Yılında Ortalama Aylık Brüt Ücrete Göre Meslek Siralaması

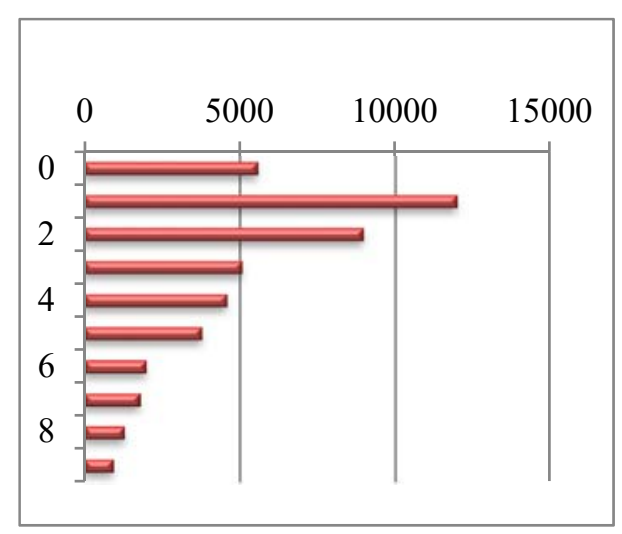

Şekil 4. 2013 Yılında Ortalama Aylık Brüt Ücrete Göre Meslek Siralaması

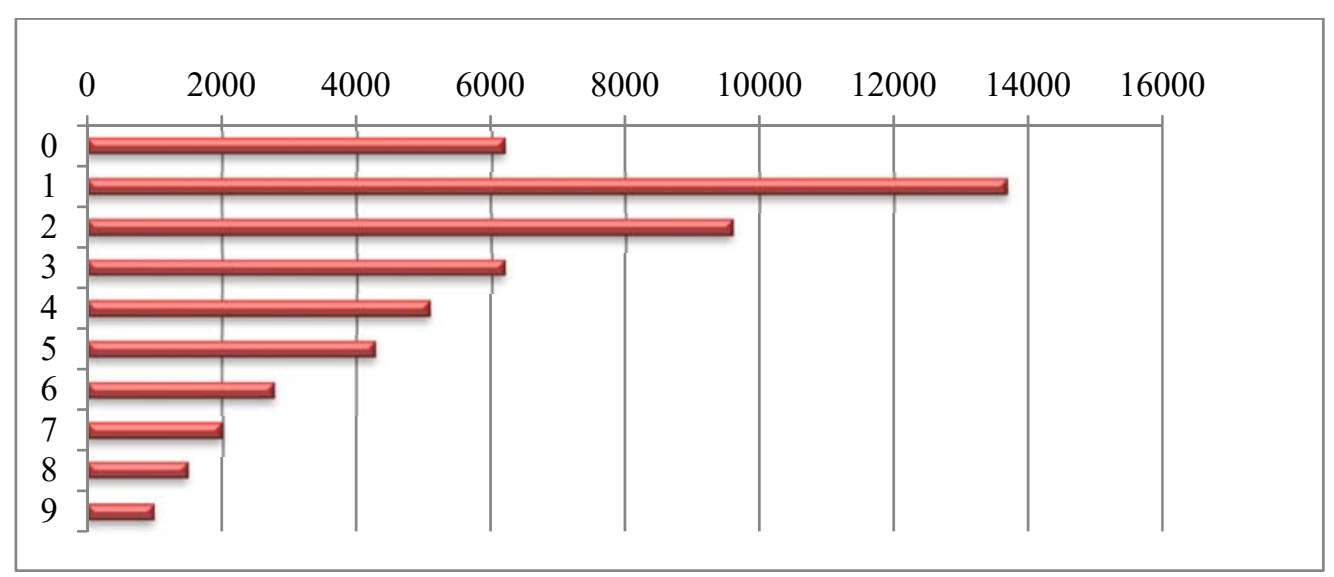

Şekil 5. 2014 Yılında Ortalama Aylık Brüt Ücrete Göre Meslek Sıralaması 
Araştırmanın değişkeni brüt (nominal) aylık ücrettir. Veriler Türkiye'de iş ve iş dışı sektörlerde çalışanları kapsamaktadır. Özel (iş) sektörde yapılan işler için çalışanlara ücret ödenmekte ve bütçesel (ulusal, kamu, kar amacı gütmeyen) sektörde ise maaş verilmektedir. TÜİK web sitesinde sunulan bilgiye göre "ücret" terimi hem özel sektörde, hem bütçesel sektörde kazanılan ve ödenen paraya denilmektedir. Veriler, aralıkların eşitsiz genişlikte ve aşırı açıklıkta olan aralık frekans dağılımı şeklindedir. Tekil veri şu anda mevcut değildir. Şekiller 1-5, 2010-2014 döneminde ortalama aylık brüt ücrete göre meslek sıralamasını göstermektedir. Meslek sıralamasının tüm dönem boyunca değişmediği açıktır. Üç en çok ve üç en az kazandıran meslekler seçilmiştir ve toplam 24 ücret dağılımı incelenmiştir. Tablo 2, üç en çok ve üç en az kazandıran mesleklerin örneklem büyüklüğünü göstermektedir.

Tablo 2. En Çok ve En Az Kazandıran Mesleklerin Örneklem Büyüklükleri (Çalışan Sayıs1)

\begin{tabular}{|c|l|c|c|c|c|c|}
\hline \multicolumn{2}{|c|}{ Meslek } & \multicolumn{4}{|c|}{ Y1l } \\
\cline { 3 - 7 } \multicolumn{2}{|c|}{} & 2010 & 2011 & 2012 & 2013 & 2014 \\
\hline \multirow{3}{*}{$\begin{array}{l}\text { En Çok } \\
\text { Kazanan }\end{array}$} & Yöneticiler & 9,700 & 10,800 & 11,200 & 12,000 & 13,700 \\
\cline { 2 - 7 } & Uzmanlar & 7,000 & 7,600 & 8,200 & 9,000 & 9,600 \\
\cline { 2 - 7 } & $\begin{array}{l}\text { Teknik Elemanlar ve Uzman } \\
\text { Yardımcıları }\end{array}$ & 3,700 & 4,000 & 4,600 & 5,100 & 6,200 \\
\hline \multirow{3}{*}{$\begin{array}{l}\text { En Az Gerektirmeyen } \\
\text { Kazanan }\end{array}$} & $\begin{array}{l}\text { Nitelik } \\
\text { İşlerde Çalışanlar }\end{array}$ & 800 & 800 & 900 & 950 & 100 \\
\cline { 2 - 7 } & Hizmet ve Satış Elemanları & 1,000 & 1,000 & 1,200 & 1,300 & 1,500 \\
\cline { 2 - 7 } & $\begin{array}{l}\text { Vasıflı Tarım, Ormancılık } \\
\text { Ve Balıkçılık İşçileri }\end{array}$ & 1,200 & 1,500 & 1,800 & 2,000 & 2,800 \\
\hline
\end{tabular}

Kaynak: Kişisel araştırmalar (OECD, TUIK, EUROSTAT, WORLD BANK).

\section{EN CCOK VE EN AZ KAZANAN MESLEKLERDE ÜCRET DAĞILIMI}

Belirli bir yıl içinde belirli bir meslek içindeki tüm çalışanlar eşit değerlendirilirse, onların ücreti ortalama ücret değerine denk gelir. Ancak 


\section{M.İ. YENILMEZ- M.H.DEMIR}

bunların yaklaşık üçte ikisi bu miktara ulaşamamaktadır, çünkü diğer çalışanlar ortalamamın birkaç kez daha fazlasını kazanmaktadırlar, özellikle en çok kazandıran mesleklerde. Ücret düzeyi özellikleri aritmetik ortalama ve medyan (yani orta ücret) olup çalışanların yarısı her ay bu miktardan az veya ona eşit ücret almaktadır. $\mathrm{Bu}$ iki ücret düzeyi özelliklerinin karşılaştırması gösteriyor ki, tüm incelenen ücret dağılımları için "medyan < ortalama" ilişkisi geçerlidir. Bu durum, pozitif çarpıklık ile karakterize edilen ücret ve gelir dağılımı için tipik bir ilişkidir. Medyan ile ifade edilen ücret düzeyi böylece ücret ortalamalarının altındadır.

En Çok Kazandıran Mesleklerde Aylık Brüt Ücret Gelişimi

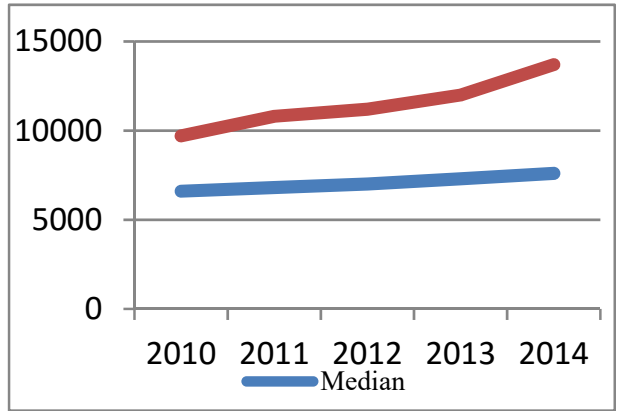

Şekil 6. Yöneticiler

En Çok Kazandıran Mesleklerde Aylık Brüt Ücret Gelişimi

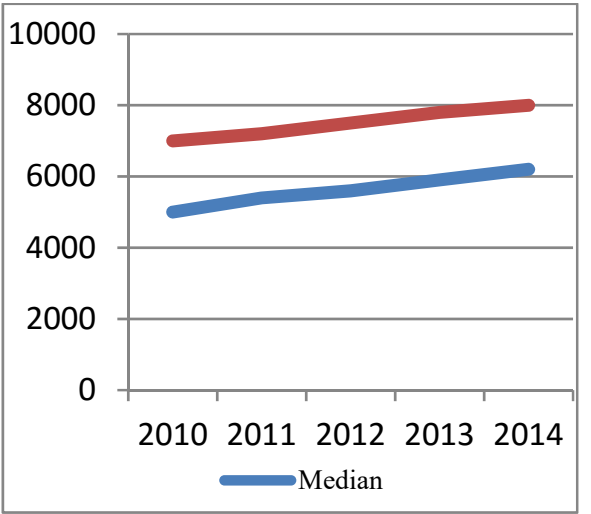

Şekil 8. Uzmanlar
En Az Kazandıran Mesleklerde Aylık Brüt Ücret Gelişimi

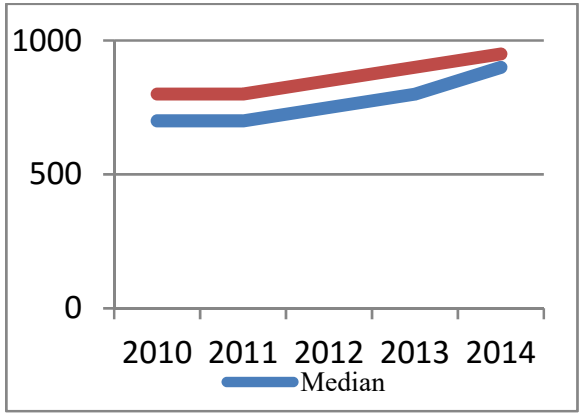

Şekil 7. Nitelik Gerektirmeyen Meslekler

En Az Kazandıran Mesleklerde Aylık Brüt Ücret Gelişimi

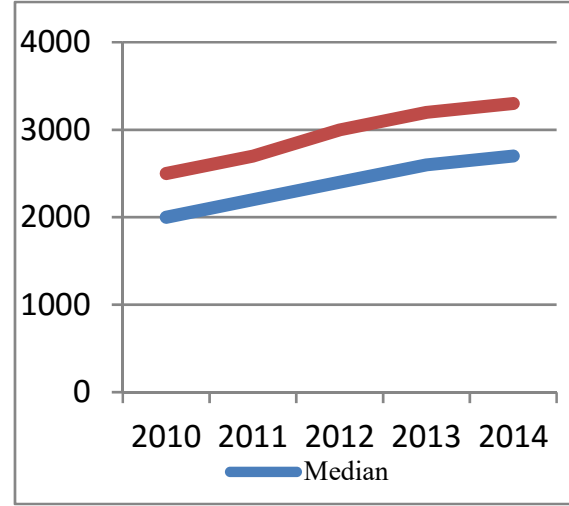

Şekil 9. Hizmet ve Satış Elemanları 


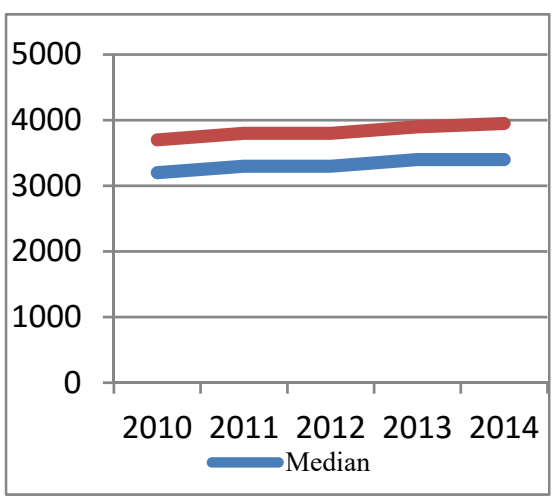

Şekil 10. Teknik Elemanlar, Uzman Yardımcıları

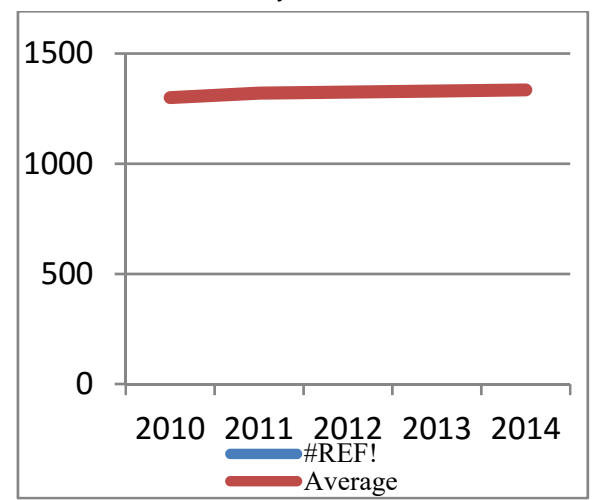

Şekil 11. Vasıflı Tarım, Ormancılık, Balıkçılık

Şekiller 6-11, en çok ve en az kazandıran meslekler arasında ücret dağılım düzeyini karşılaştırma imkânı vermektedir. Yöneticilerin nitelik gerektirmeyen mesleklerde çalışanlara göre ortalama neredeyse dört kat daha fazla ücret kazandıkları açıktır. Bu rakamlar ve Tablo 3, ücret dağılımında çarpıklık hakkında bilgiler vererek aylık brüt ücretin aritmetik ortalama ve ilgili medyan değerlerini karşılaştırmaktadırlar. Yukarıda da belirtildiği gibi, medyan değeri ve aritmetik ortalama arasındaki ilişki, örneğin, ücret medyanının ortalama ücretten daha düşük olması gibi, pozitif çarpık dağılım için tipiktir. Başka bir deyişle, ücret medyanı aritmetik ortalamaya ne kadar yakınsa (yani medyanın aritmetik ortalamaya daha yüksek oranı), o kadar da ücret dağılımı daha az pozitif çarpık olur. Tablo 3, orta ve ortalama aylık brüt ücretin yüzde oranlarını göstermektedir. Şekiller 6-11 ve Tablo 3'ten anlaşıldığı gibi, ülke genelinde çok çalışanının oldukça yüksek ücretler aldığı en çok kazandıran mesleklerde ücret dağılımları en çok pozitif çarpıklığı ortaya çıkarmaktadır. Bunun yanında, yüksek ücretlerin oldukça nadir rastlandığı en az kazandıran mesleklerde ücret dağılımları en az pozitif çarpıklığı göstermektedir. 


\section{M.İ. YENILMEZ- M.H.DEMIR}

Tablo 3. Aylık Orta ve Ortalama Brüt Ücret Yüzdesi Oranı - Çarpıklık Göstergesi

\begin{tabular}{|c|c|c|c|c|c|c|}
\hline \multirow{2}{*}{\multicolumn{2}{|c|}{ Meslek }} & \multicolumn{5}{|c|}{ Yil } \\
\hline & & 2010 & 2011 & 2012 & 2013 & 2014 \\
\hline \multirow{3}{*}{$\begin{array}{l}\text { En çok } \\
\text { kazanan }\end{array}$} & Yöneticiler & 74.89 & 68.26 & 71.64 & 72.15 & 73.41 \\
\hline & Uzmanlar & 81.62 & 80.57 & 80.91 & 81.55 & 81.73 \\
\hline & $\begin{array}{c}\text { Teknik elemanlar ve uzman } \\
\text { yardımcıları }\end{array}$ & 91.35 & 90.83 & 90.11 & 90.46 & 90.91 \\
\hline \multirow{3}{*}{$\begin{array}{l}\text { En az } \\
\text { kazanan }\end{array}$} & Nitelik gerektirmeyen meslekler & 94.07 & 92.67 & 92.16 & 91.80 & 92.23 \\
\hline & Hizmet ve satış elemanları & 88.91 & 88.89 & 89.04 & 88.42 & 88.14 \\
\hline & $\begin{array}{l}\text { Vasıflı tarım, ormancılık ve } \\
\text { balıkçılık işçileri }\end{array}$ & 95.72 & 95.87 & 96.48 & 97.05 & 97.28 \\
\hline
\end{tabular}

Kaynak: Kişisel araştırmalar (OECD, TUIK, EUROSTAT, WORLD BANK).

Tablo 4, bireysel mesleklerde ücret düzeyinin en çok kazandıran mesleklerde ücret düzeyine (yani idari personelin) yüzde oranı hakkında fikir vererek, tüm incelenen mesleklerde ücret düzeyi oranlarındaki artış eğilimine de işaret etmektedir.

Şekiller 12-17, araştırma dönemi boyunca ortalama ve orta aylık brüt ücretin yıllık büyüme oranı gelişimi hakkında bilgi vermektedirler. 2010 yılı büyüme oranı 2009 verileri mevcut olmadığından dolayı hesaplanmamıştır.

Tablo 4. Bireysel mesleklerde ücret düzeyinin yöneticilere nazaran yüzde oranı

\begin{tabular}{|c|c|c|c|c|c|c|}
\hline \multicolumn{7}{|c|}{ Meslek } \\
\hline Y1l & İstatistik & Uzmanlar & $\begin{array}{l}\text { Teknik } \\
\text { elemanlar } \\
\text { ve } \\
\text { yardımcı } \\
\text { uzmanlar }\end{array}$ & $\begin{array}{l}\text { Nitelik } \\
\text { gerektirmeyen }\end{array}$ & $\begin{array}{l}\text { Hizmet ve } \\
\text { satış } \\
\text { elemanları }\end{array}$ & $\begin{array}{l}\text { Vasıflı tarım, } \\
\text { ormancılık } \\
\text { ve balıkçılık } \\
\text { işçileri }\end{array}$ \\
\hline \multirow{2}{*}{2010} & Ortalama & 71.83 & 52.71 & 25.10 & 29.74 & 32.25 \\
\hline & Medyan & 75.18 & 60.37 & 32.91 & 34.60 & 41.72 \\
\hline
\end{tabular}


Dokuz Eylül Üniversitesi İktisadi ve İdari Bilimler Fakültesi Dergisi Cilt:32, Sayl:1, Yll:2017, ss. 243-269

\begin{tabular}{|c|l|r|r|r|r|r|}
\hline \multirow{2}{*}{2011} & Ortalama & 72.16 & 53.06 & 26.72 & 29.96 & 35.17 \\
\cline { 2 - 7 } & Medyan & 73.82 & 63.18 & 33.68 & 35.81 & 43.26 \\
\hline \multirow{2}{*}{2012} & Ortalama & 74.31 & 53.87 & 27.91 & 30.71 & 35.82 \\
\cline { 2 - 7 } & Medyan & 76.04 & 63.18 & 31.88 & 34.07 & 43.91 \\
\hline \multirow{2}{*}{2013} & Ortalama & 76.90 & 55.14 & 28.04 & 31.15 & 36.83 \\
\cline { 2 - 7 } & Medyan & 78.83 & 63.85 & 32.91 & 36.73 & 45.27 \\
\hline \multirow{2}{*}{2014} & Ortalama & 78.03 & 56.83 & 28.44 & 32.64 & 37.75 \\
\cline { 2 - 7 } & Medyan & 79.15 & 65.17 & 34.17 & 35.29 & 46.08 \\
\hline
\end{tabular}

En Çok Kazandiran Mesleklerde Yıllık Büyüme Oranı Gelişimi (\%)

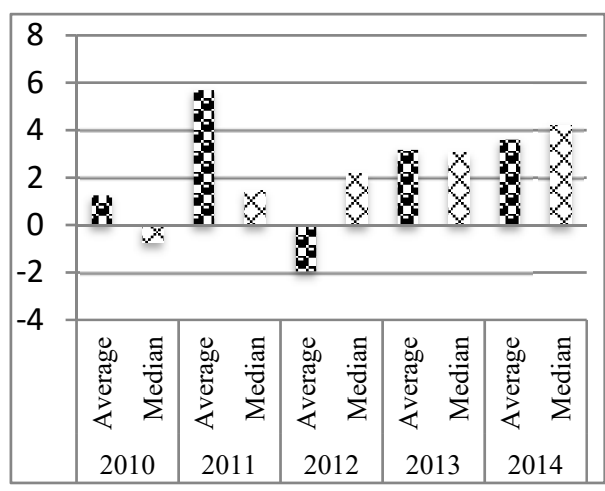

Şekil 12. Yöneticiler

En Çok Kazandıran Mesleklerde Yıllık Büyüme Oranı Gelişimi (\%)

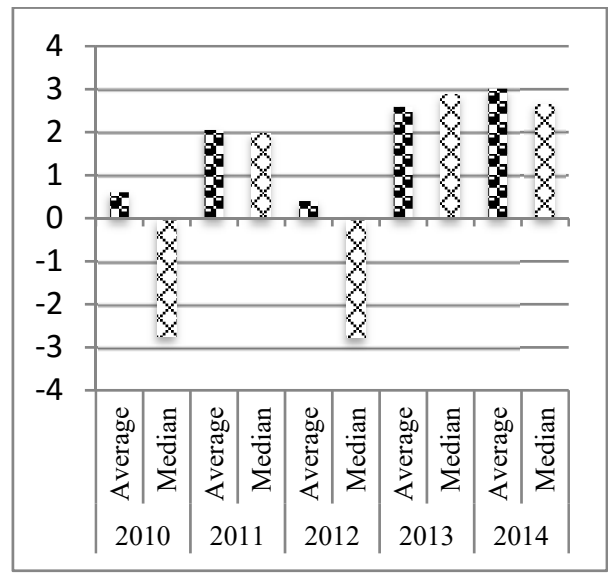

Şekil 14. Uzmanlar
En Az Kazandıran Mesleklerde Yıllık Büyüme Hızının Gelişimi (\%)

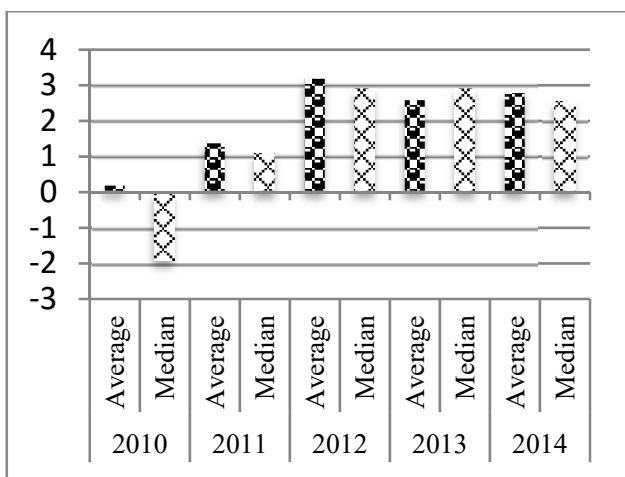

Şekil 13. Nitelik Gerektirmeyen Meslekler

En Az Kazandıran Mesleklerde Y1llık Büyüme Hızının Gelişimi (\%)

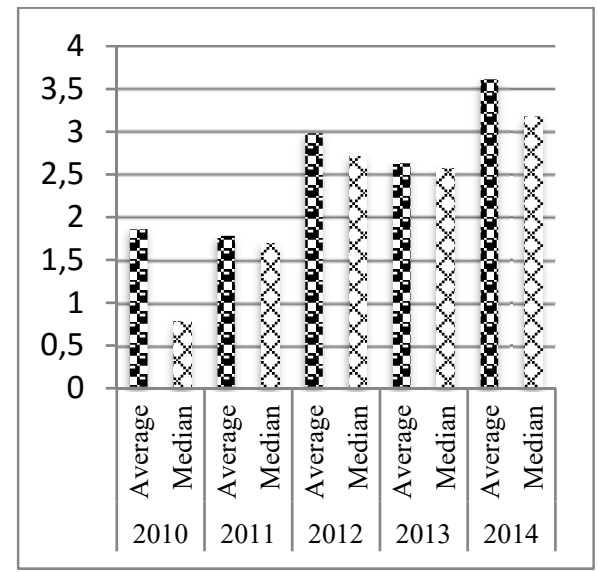

Şekil 15. Hizmet ve Satış Elemanları 
M.İ. YENILMEZ- M.H.DEMIR

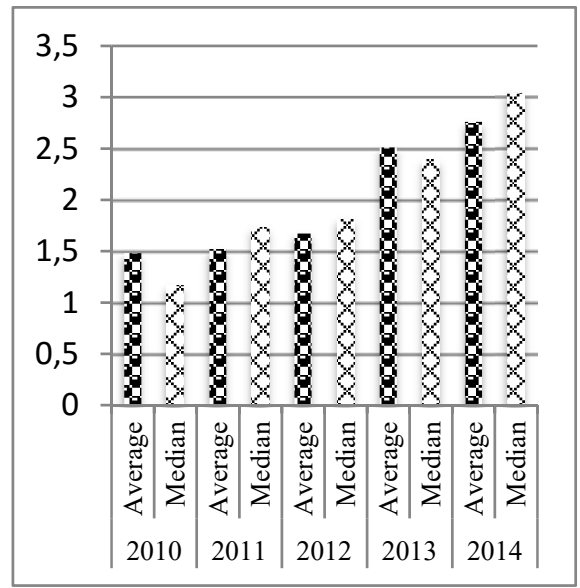

Şekil 16. Teknik Elemanlar, Uzman

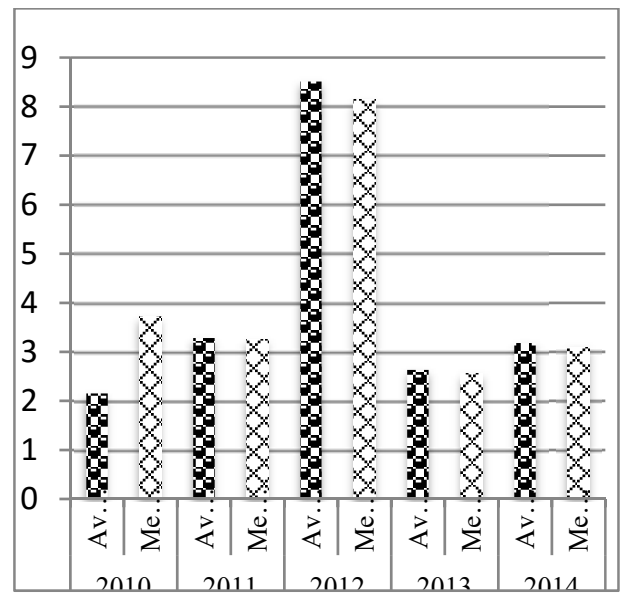

Şekil 17. Vasıflı Tarım, Ormancılık Yardımcıları ve Balıkçılık

$\mathrm{Bu}$ rakamlar, ortalama ve orta ücretin davranışları arasında belirli bir farklıllğa işaret etmektedir. Şekil 12'de, örneğin, 2013 yllında yönetici pozisyonlarında ortalama ücretin, aynı ücret dağılımında orta ücrette $\% 3,17$ artışa karşın, y1llık \% 3,05’e düştüğü gösterilmektedir. Benzer bir durum, ama ters anlamda - orta ücret düşerken, ortalama ücret artmakta - 2012 y1linda uzmanlar ve nitelik gerektirmeyen meslekler grubunda meydana gelmiştir. Şekil 14'de gösterildiği gibi, ilk grubun ortalama aylık brüt ücreti $\% 0,40$ oranında biraz artmış ve orta aylık brüt ücreti de \% 2,78 azalmıştır. En az kazandıran mesleklerde ortalama ücret \% 0,78 civarında biraz yükselmiş ve onların orta ücreti \% 1,73 düşmüştür; bkz., Şekil 13. 2012 y1lı ücret düzeyinde en büyük artış nitelikli tarım, ormancıllk ve su ürünleri çalışanları arasında ortalama ve orta ücretin sırasıyla $\% 8,51$ ve $\% 8,14$ artışıla görülebilir. Kriz sonrası yıl olarak kabul edilen 2014 yılında en çok ve en az kazandıran mesleklerde ücret düzeyleri, ortalama ve orta aylık brüt ücrette \% 2,56 ile \% 4,60 arasında değişen y1llık büyüme oranlarıyla artmıştır. Tablo 5, 2010 ve 2014 yılları arasında ortalama yıllık büyüme oranı hakkında bilgi vermektedir. Bu verilere dayanarak, nitelikli tarım, 
ormancılık ve su ürünleri çalışanları grubunda ücret düzeyinin, ortalama ve orta ücretin sırasıyla yıllık \% 3,95 ve \% 4,36 oranında artarak, genel olarak hızlı büyüdügü söylenebilir. Uzmanlar grubunda ortalama ve orta ücretin yıllık büyüme oranları arasında önemli farklılıklar görülmektedir: ortalama olarak her yıl aylık ortalama brüt ücret $\% 2,18$ artarken, aylık orta brüt ücret ise sadece $\% 0,92$ artmıştır.

Tablo 6, 2010-2014 dönemi boyunca en çok ve en az kazandıran mesleklerde mutlak ve göreli değişkenlik özelliklerinin gelişimi hakkında bilgi vermektedir. Standart sapma, bireysel çalışan ücretlerinin onların ortalama ücretlerinden sapmalarının ikinci dereceden ortalaması olarak tanımlanan mutlak değişkenlik özelliğini temsil etmektedir. Bununla bireysel çalışan ücretlerinin nasıl ortalama ücretlerden farklılaştığ gösterilmektedir. Varyasyon katsayısı, ücretlerin ilgili ortalama ücrete standart sapma oranı olarak tanımlanan göreli değişkenliği nitelendirmektedir. Bu boyutsuz sayı, yüz ile çarpılarak ortalama ücrette standart sapma payı yüzdesini göstermektedir. Tablo 6'da açıkça görüldüğü gibi, mutlak değişkenlik özelliği olarak standart sapma, artan ücret düzeyleriyle birlikte artma eğilimindedir. Bu durumda, varyasyon katsayısı göreli değişkenliğin daha uygun özelliğidir, çünkü mutlak değişkenliği istatistiksel örneklemde ücret düzeyi ile ilgili ölçmektedir. Varyasyon katsayısının en yüksek değerleri \% 51,06 ve \% 52,84 olarak hizmet ve satış elemanları grubunda kaydedilmiştir. Ancak bu durum düşüş eğilimini göstermektedir. Varyasyon katsayısının ikinci en yüksek değerleri, 2011 yılındaki \% 45,41 ile 2012 yılındaki \% 47,56 arasında değişen değerler ile, en az kazandıran nitelik gerektirmeyen meslekler ile ilişkilidir. En çok kazanan yöneticiler üçüncü sırada yer almaktadır. Diğer taraftan, ikinci en çok kazanan grup olarak uzmanlar, \% 31 civarında dalgalanan değişkenlik katsayısı ile en düşük değerlere sahiptirler. 


\section{M.İ. YENILMEZ- M.H.DEMIR}

Tablo 5. Aylık Brüt Ücretin Yıllık Ortalama Büyüme Hızı (\% Olarak)

\begin{tabular}{|c|c|c|c|}
\hline \multicolumn{2}{|r|}{ Meslek } & $\dot{I}_{\text {ctotictil }}$ & $\varnothing$ \\
\hline \multirow{4}{*}{ 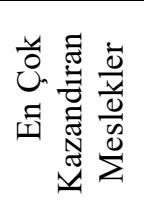 } & \multirow{2}{*}{ Yöneticiler } & Ortalama & 2,43 \\
\hline & & 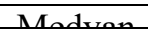 & 228 \\
\hline & Uzmanlar & Ortalama & 2,18 \\
\hline & Teknik elemanlar ve uzman yardımcıları & Ortalama & 1,75 \\
\hline \multirow{4}{*}{ 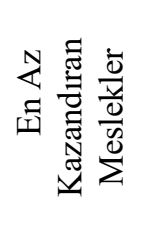 } & Nitelik gerektirmeyen meslekler & Ortalama & 1,76 \\
\hline & Hizmet ve satış elemanları & Ortalama & 2,19 \\
\hline & \multirow{2}{*}{$\begin{array}{l}\text { Vasıflı tarım, ormancılık ve balıkçılık } \\
\text { işçileri }\end{array}$} & Ortalama & 3,95 \\
\hline & & Medvar & $-5+2$ \\
\hline
\end{tabular}

Tablo 7, seçilen yüksek maaşlı idari personel alt grubunun aylık ortalama brüt ücreti hakkında bilgi vermektedir. Biz, mesela, tüm dönem boyunca sadece finans ve sigorta hizmetlerinde şube müdürlerinin ortalama ücretinin 120.000 t aştığını, genel müdürler ve başkanların ortalama aylık brüt ücretlerinin 10.000 t ile $15.000 \downarrow$ arasında dalgalandığını, bilgi ve iletişim teknolojilerinde teknik servis müdürlerinin ise ayda ortalama yaklaşı 80.000 t kazandığını görebilmekteyiz.

Tablo 6. Mutlak ve Göreli Değişkenlik Özellikleri - Standart Sapma (TL) ve Varyasyon Katsayıs1 (\%)

\begin{tabular}{|c|c|c|c|c|c|c|}
\hline & \multirow[b]{2}{*}{ Meslek } & \multirow[b]{2}{*}{ İstatistik } & \multicolumn{4}{|c|}{ Y11 } \\
\hline & & & 2011 & 2012 & 2013 & 2014 \\
\hline \multirow{6}{*}{ 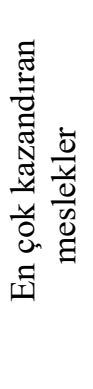 } & \multirow{2}{*}{ Yöneticiler } & Standart sapma & 22.161 & 24.333 & 23.165 & 24.213 \\
\hline & & Değişim katsayısı & 40,18 & 41,71 & 40,52 & 40,85 \\
\hline & \multirow{2}{*}{ Uzmanlar } & Standart sapma & 11.392 & 11.536 & 11.818 & 11.898 \\
\hline & & Değişim katsayısı & 31,32 & 31,53 & 31,36 & 30,78 \\
\hline & \multirow{2}{*}{$\begin{array}{l}\text { Teknik } \\
\text { elemanlar } \\
\text { uzman }\end{array}$} & Standart sapma & 10.675 & 10.675 & 10.796 & 10.915 \\
\hline & & Değişim katsayısı & 37,63 & 37,09 & 37,05 & 36,53 \\
\hline
\end{tabular}


Dokuz Eylül Üniversitesi İktisadi ve İdari Bilimler Fakültesi Dergisi

Cilt:32, Sayl:1, Yll:2017, ss. 243-269

\begin{tabular}{|c|c|c|c|c|c|c|}
\hline \multirow{6}{*}{ 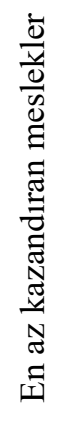 } & \multirow{2}{*}{$\begin{array}{l}\text { Nitelik } \\
\text { gerektirmeyen } \\
\text { meslekler }\end{array}$} & Standart sapma & 6.626 & 6.956 & 6.975 & 7.134 \\
\hline & & Değişim katsayısı & 45,41 & 47,56 & 46,78 & 46,41 \\
\hline & \multirow{2}{*}{$\begin{array}{l}\text { Hizmet } \\
\text { satış } \\
\text { elemanları }\end{array}$} & Standart sapma & 8.520 & 8.584 & 8.575 & 8.785 \\
\hline & & Değişim katsayısı & 52,84 & 52,20 & 51,33 & 51,06 \\
\hline & \multirow{2}{*}{$\begin{array}{l}\text { Vasıflı tarım, } \\
\text { ormancılık ve } \\
\text { balıkçılık } \\
\text { işçileri }\end{array}$} & ,Standart sapma & 6.192 & 5.944 & 5.827 & 5.887 \\
\hline & & Değişim katsayısı & 36,05 & 31,60 & 30,31 & 29,65 \\
\hline
\end{tabular}

Tablo 7. En Çok Kazanan Yöneticilerin Alt Gruplarda Aylık Ortalama Brüt Ücret

\begin{tabular}{|c|c|c|c|c|c|}
\hline \multirow[b]{2}{*}{ Mesleki Alt Grup } & \multirow{2}{*}{$\begin{array}{l}\text { TÜİK } \\
\text { Sınıflandırması }\end{array}$} & \multicolumn{4}{|c|}{ Yil } \\
\hline & & 2011 & 2012 & 2013 & 2014 \\
\hline $\begin{array}{l}\text { Üst düzey hükümet } \\
\text { yetkilileri }\end{array}$ & 1112 & 53.189 & 52.731 & 54.383 & 52.335 \\
\hline $\begin{array}{l}\text { Genel müdürler ve } \\
\text { başkanlar }\end{array}$ & 1120 & 80.430 & 87.434 & 82.199 & 85.674 \\
\hline \multirow[b]{2}{*}{ Mesleki Alt Grup } & \multirow{2}{*}{$\begin{array}{c}\text { TÜİK } \\
\text { Sinıflandırması }\end{array}$} & \multicolumn{4}{|c|}{ Yil } \\
\hline & & 2011 & 2012 & 2013 & 2014 \\
\hline Finans yöneticileri & 1211 & 72.806 & 75.680 & 72.806 & 75.583 \\
\hline $\begin{array}{l}\text { İnsan kaynakları } \\
\text { yöneticileri }\end{array}$ & 1212 & 63.152 & 68.126 & 67.320 & 67.887 \\
\hline $\begin{array}{l}\text { Başka yerde } \\
\text { sinıflandırılmamış iş } \\
\text { hizmetleri ve idaresi } \\
\text { yöneticileri }\end{array}$ & 1219 & 53.242 & 54.968 & 55.573 & 57.003 \\
\hline $\begin{array}{l}\text { Satış ve pazarlama } \\
\text { yöneticisi }\end{array}$ & 1221 & 64.285 & 68.058 & 66.134 & 72.855 \\
\hline $\begin{array}{l}\text { Araştırma ve } \\
\text { geliştirme yöneticileri }\end{array}$ & 1223 & 63.684 & 70.389 & 72.002 & 74.341 \\
\hline $\begin{array}{l}\text { Tarım ve ormancilik } \\
\text { üretim yöneticileri }\end{array}$ & 1311 & 39.202 & 40.397 & 41.632 & 41.232 \\
\hline Üretim yöneticileri & 1321 & 60.583 & 62.140 & 63.590 & 64.041 \\
\hline $\begin{array}{l}\text { Madencilik } \\
\text { yöneticileri }\end{array}$ & 1322 & 74.046 & 79.504 & 63.861 & 70.788 \\
\hline İnşaat yöneticileri & 1323 & 45.375 & 45.180 & 43.841 & 46.603 \\
\hline
\end{tabular}


M.I. YENILIMEZ- M.H.DEMIR

\begin{tabular}{|c|c|c|c|c|c|}
\hline $\begin{array}{l}\text { Tedarik, dağıtım ve } \\
\text { ilgili yöneticileri }\end{array}$ & 1324 & 46.187 & 47.014 & 49.110 & 53.184 \\
\hline $\begin{array}{lll}\text { Bilgi ve } & \text { iletişim } \\
\text { teknolojisi } & \text { hizmeti } \\
\text { yöneticileri } & \\
\end{array}$ & 1330 & 76.453 & 79.902 & 81.836 & 82.984 \\
\hline $\begin{array}{lr}\text { Çocuk } & \text { bakım } \\
\text { hizmetleri yöneticileri }\end{array}$ & 1341 & 30.897 & 32.353 & 33.209 & 34.929 \\
\hline $\begin{array}{l}\text { Sağllk hizmetleri } \\
\text { yöneticileri }\end{array}$ & 1342 & 58.044 & 59.758 & 62.437 & 65.538 \\
\hline $\begin{array}{lr}\text { Yaşli } & \text { bakım } \\
\text { hizmetleri yöneticileri }\end{array}$ & 1343 & 32.837 & 33.062 & 34.178 & 35.784 \\
\hline $\begin{array}{ll}\text { Sosyal } & \text { yardım } \\
\text { yöneticileri } & \end{array}$ & 1344 & 33.390 & 34.512 & 35.561 & 35.318 \\
\hline \multirow[b]{2}{*}{ Mesleki Alt Grup } & TÜİK & \multicolumn{4}{|c|}{ Yil } \\
\hline & Sinıflandırması & 2011 & 2012 & 2013 & 2014 \\
\hline Eğitim yöneticileri & 1345 & 40.806 & 40.929 & 42.227 & 43.849 \\
\hline $\begin{array}{lr}\begin{array}{l}\text { Finans ve } \\
\text { hizmetleri } \\
\text { yöneticileri }\end{array} & \text { şube } \\
\end{array}$ & 1346 & 105.901 & 120.383 & 106.343 & 110.152 \\
\hline $\begin{array}{lc}\text { Başka } & \text { yerde } \\
\text { siniflandırılmamış } \\
\text { profesyonel hizmet } \\
\text { yöneticileri }\end{array}$ & 1349 & 47.429 & 45.114 & 45.146 & 45.578 \\
\hline Otel yöneticileri & 1411 & 32.854 & 33.207 & 34.113 & 34.743 \\
\hline Restoran yöneticileri & 1412 & 24.680 & 25.352 & 26.055 & 26.087 \\
\hline $\begin{array}{l}\text { Perakende ve toptan } \\
\text { satış yöneticileri }\end{array}$ & 1420 & 33.561 & 32.341 & 32.522 & 34.435 \\
\hline $\begin{array}{lr}\text { Spor, dinlenme ve } \\
\text { kültür } & \text { merkezi } \\
\text { yöneticileri } & \\
\end{array}$ & 1431 & 36.592 & 38.404 & 41.232 & 37.004 \\
\hline $\begin{array}{l}\text { Başka yerde } \\
\text { siniflandırılmamış } \\
\text { hizmet yöneticileri }\end{array}$ & 1439 & 42.632 & 39.042 & 38.533 & 38.190 \\
\hline
\end{tabular}

Tablo 8, en az kazanan işçiler üzerinde odaklanmaktadır. Ofisler, oteller ve diğer işyerlerinde temizlikçi ve yardımcıları olarak çalışanlar brüt olarak yaklaşı 18.000 Ł kazanmaktadırlar. Onlar aylık ortalama brüt ücret olarak finans ve sigorta hizmetleri şube müdürlerinden neredeyse dokuz kat daha 
Dokuz Eylül Üniversitesi İktisadi ve İdari Bilimler Fakültesi Dergisi Cilt:32, Sayl:1, Yll:2017, ss. 243-269

az ücret kazanmaktadırlar. Nitelik gerektirmeyen mesleklerde çalışanlar, elde çamaşır yıkayanlar ve ütücüler, çöpçü ve ilgili işçiler biraz daha yüksek ücret kazanmaktadır.

Tablo 8. En Az Kazandıran Nitelik Gerektirmeyen Mesleklerin Alt Gruplarında Aylık Ortalama Brüt Ücret (TL)

\begin{tabular}{|c|c|c|c|c|c|}
\hline \multirow[b]{2}{*}{ Mesleki Alt Grup } & \multirow{2}{*}{$\begin{array}{c}\text { TÜİK } \\
\text { Sinıflandırması }\end{array}$} & \multicolumn{4}{|c|}{ Y11 } \\
\hline & & 2011 & 2012 & 2013 & 2014 \\
\hline $\begin{array}{l}\text { Ofisler, oteller ve } \\
\text { diğer işyerlerinde } \\
\text { temizlikçi ve } \\
\text { yardımcıları }\end{array}$ & 9112 & 12.362 & 12.293 & 12.370 & 12.570 \\
\hline $\begin{array}{l}\text { Elde çamaşır } \\
\text { yıkayanlara ve ütücüler }\end{array}$ & 9121 & 13.228 & 13.386 & 13.027 & 13.669 \\
\hline $\begin{array}{l}\text { Maden ve taşocağ } 1 \\
\text { işçileri }\end{array}$ & 9311 & 22.110 & 22.189 & 22.563 & 22.275 \\
\hline Bina inşaatı işçileri & 9313 & 15.975 & 16.168 & 16.728 & 15.909 \\
\hline $\begin{array}{l}\text { Elle paketleme } \\
\text { işçileri }\end{array}$ & 9321 & 17.012 & 17.051 & 16.631 & 17.093 \\
\hline $\begin{array}{l}\text { Başka yerde } \\
\text { sınıflandırılma } \\
\text { mış imalat } \\
\text { ișçileri }\end{array}$ & 9329 & 15.453 & 15.595 & 16.475 & 17.226 \\
\hline Yük işlemcileri & 9333 & 17.521 & 17.376 & 17.645 & 18.020 \\
\hline $\begin{array}{l}\text { Mutfak } \\
\text { yardımcıları }\end{array}$ & 9412 & 11.138 & 11.659 & 11.793 & 12.139 \\
\hline $\begin{array}{l}\text { Çöp ve geri dönüşüm } \\
\text { toplayıcıları }\end{array}$ & 9611 & 18.014 & 18.596 & 18.544 & 19.045 \\
\hline Çöpçü ve ilgili işçiler & 9613 & 13.258 & 13.721 & 13.024 & 13.202 \\
\hline $\begin{array}{l}\text { Kuryeler, koli } \\
\text { dağıtıcıları ve bagaj } \\
\text { taşıyıcıları }\end{array}$ & 9621 & 19.050 & 17.445 & 18.456 & 17.077 \\
\hline $\begin{array}{l}\text { Ufak tefek ayak } \\
\text { işlerinde } \\
\text { çalışanlar } \\
\text { (Angarya } \\
\text { işçileri) }\end{array}$ & 9622 & 15.439 & 15.066 & 15.111 & 17.077 \\
\hline
\end{tabular}


M.İ. YENILMEZ- M.H.DEMİR

\begin{tabular}{|l|c|c|c|c|c|}
\hline $\begin{array}{l}\text { Sayaç okuyucuları ve } \\
\text { otomatik satış } \\
\text { makinesinden para } \\
\text { toplayıcıları }\end{array}$ & 9623 & 19.815 & 20.685 & 21.429 & 21.842 \\
\hline $\begin{array}{l}\text { Başka yerde } \\
\text { sinıflandırılmamış } \\
\text { nitelik gerektirmeyen } \\
\text { mesleklerde çalışanlar }\end{array}$ & 9629 & 12.585 & 12.520 & 12.280 & 12.936 \\
\hline
\end{tabular}

En çok kazandıran mesleklerde ortalama aylık brüt ücretleri arasında büyük boşluklar Tablo 7'de açık olarak gösterilmektedir: 2014 yılında finans ve sigorta hizmetleri şube müdürleri 138.260 kazanırken restoran yöneticileri ortalama sadece 45.015 t kazanmışlardır. Buna karşın, Tablo 8'de gösterilen farklar oldukça küçüktür. Örneğin, 2014 yılında madencilik ve taş ocakçılığı sektöründe çalışanlar ortalama 15,600 t kazanırken, ofisler, oteller ve diğer işyerlerinde temizlikçi ve yardımcıları aylık ortalama brüt ücret olarak 13.685 kazanmışlardır.

\section{EN ÇOK VE EN AZ KAZANAN MESLEKLERDE ÜCRET DAĞILIMI MODELLEMESI}

Tablo 9'da asgari ücretin belirli bir yıldaki düzeyi güçlü bir şekilde görülmektedir.. Tablo 9, 2013 yılında asgari brüt ücretin Ocak-Haziranda

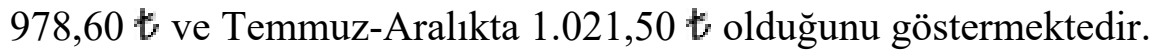

Tablo 9. Araştırma Dönemi Boyunca Asgari Ücret Gelişimi (TL)

\begin{tabular}{|l|c|c|c|c|}
\hline & \multicolumn{4}{|c|}{ Y } \\
\cline { 2 - 5 } & 2011 & 2012 & 2013 & 2014 \\
\hline Aylık Asgari Ücret & 8.000 & 8.000 & 8.000 & 8.500 \\
& & & 8.500 & \\
\hline Saatlik Asgari Ücret & \multirow{2}{*}{48,10} & 48,10 & 48,10 & 50,60 \\
& & & 50,60 & \\
\hline
\end{tabular}

Daha fazla netlik için ücret dağılım modelleri 1000 tücret aralıkları kullanmaktadırlar. Asgari ücret de bu aralık dâhilinde olduğundan ilgili 
asgari ücret 1.000 t ile 1.300 t arasında geçmektedir. En çok kazandıran mesleklerde böyle bir kesişme 1.300 t'na oldukça yakındır, çünkü bu işlerde çalışanların çoğunluğu asgari ücret almazlar. Diğer yandan, en az kazandıran mesleklerde bu kesişim noktası biraz daha aşağıdadır, çünkü çok daha fazla çalışan asgari ücret karşılığında (ya da ona yakın bir miktara) çalışmasın beklenmektedir. Kısaca asgari ücret 1000 t olarak baz alınsa bile bu sorun çözülmüş olmaz, çünkü dönem boyunca asgari ücret aynı değildir.

Teorik ücret dağılım gelişimini gösteren lognormal eğrileri en çok ve en az kazandıran meslekler arasında güçlü bir farklılık göstermektedirler. Ücretlerin sadece belirgin yüksek düzeyi ve değişkenliği değil, aynı zamanda en çok kazandıran mesleklerde ücret dağılımlarının daha yüksek çarpıklığı da dikkate alındığında, en az kazandıran mesleklerde bu göstergeler, beklendiği gibi, çok farklı davranmaktadır. Bu şekiller ayrıca net bir şekilde ücret dağılım gelişimini temsil eden lognormal eğrilerinin birbirleri ile büyük ölçüde örtüştüğünü göstermektedir, özellikle en çok kazandıran mesleklerde. Bu, ücret dağılım şeklinin ve ilgili özelliklerinin zamanla sadece biraz değiştiği bulgusuyla doğrulanmıştır. Dönem içinde olasılık yoğunluk fonksiyonu eğrileri sadece nitelikli tarım, ormancılık ve su ürünleri çalışanları için daha fazla farklılık göstermektedir. Tablo 10 verileri bu lognormal eğrilerine göre hesaplanmıştır. Bu tablo, aylık brüt ücreti olarak verilen ücrete eşit veya daha az, ve düşük ücretli mesleklerden dolayı 16.000 aşmayan, çalışanların yüzde oranlarını göstermektedir. $\mathrm{Bu}$ tablodan da anlaşılacağı üzere, örneğin, 2014 yılında yöneticilerin sadece \% 9,95 aylık brüt ücret olarak 12.000 eşit veya daha az ve \% 44,87 de maksimum 16.000 ücret kazandı. Aynı dönemde nitelik gerektirmeyen işlerde çalışanların \% 81,89'u 12.000 † eşit veya daha az aylık brüt ücret almışlardır. 


\section{M.İ. YENILLMEZ- M.H.DEMİR}

Tablo 10. Aylık Brüt Ücreti 8.000, 9.800, 10.000 Ve 16.000 TL Eşit Veya Ondan Az Olan Çalışanların Yüzde Oranları

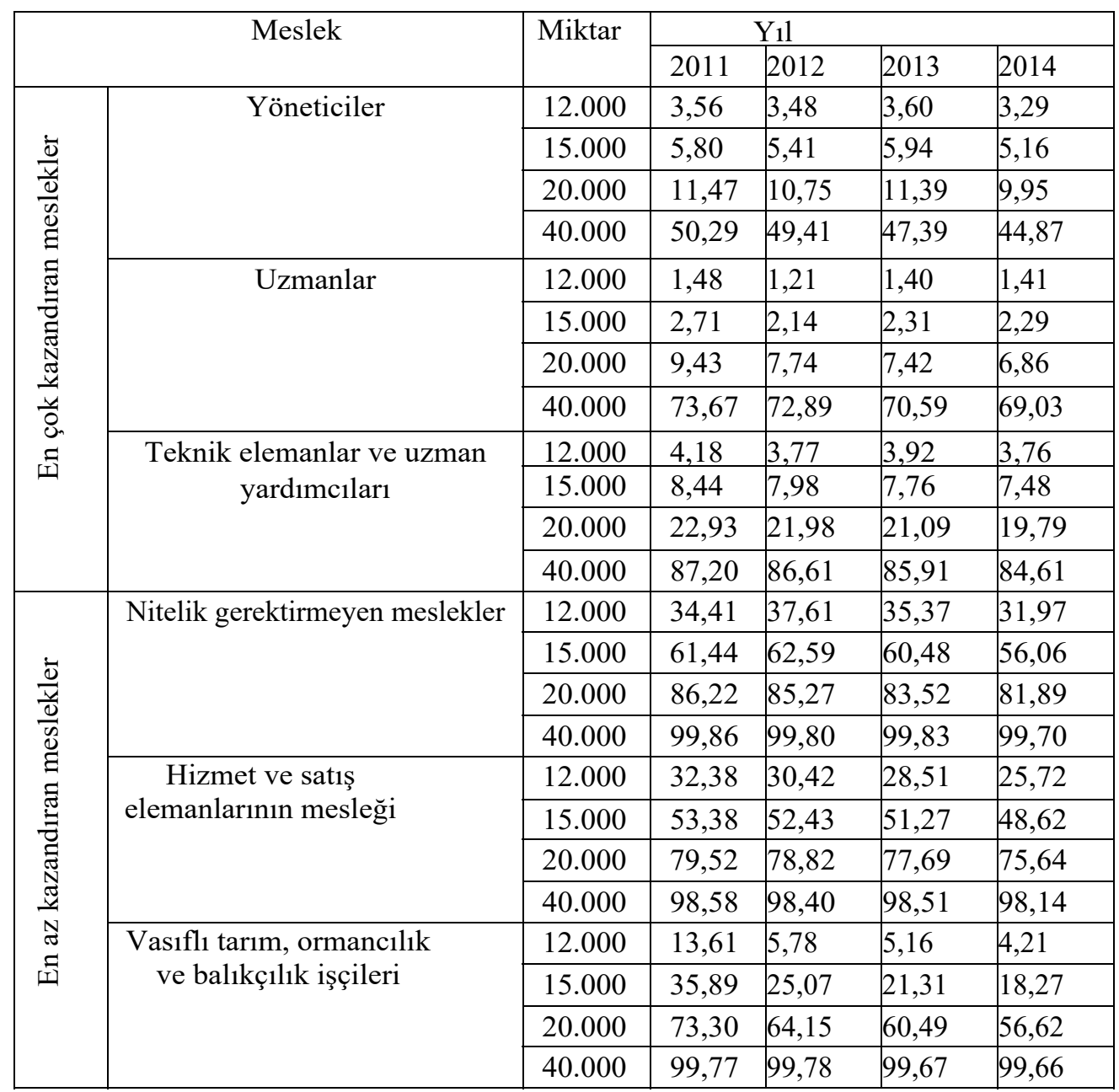

\section{AYLIK BRÜT ÜCRETİN MESLEKLERE OLAN BAĞIMLILIĞI}

Tablolar 11 ve 12 'de aylık brüt ücret ile bir meslek arasındaki istatistiksel bağımlık gösterilmektedir. Bu bağımlılık araştırma döneminin her y1lı için doğrulanmıştır. $\mathrm{Bu}$ amaç için, bir dizi test uygulanabilir, bunlardan biri de ANOVA olarak bilinen tek-yönlü varyans analizidir; bkz., Turner ve Thayer (2001). Test veri hacimleri (yani örneklem büyüklükleri) büyük olduğundan (ücret dağılımı için genellikle onlarca, yüzlerce, hatta binlerce çalışan; bkz., Tablo 2), test gücü sürekli yüksektir. Test, değişkenlerin bağımsızlığından 
en ufak sapmaları açığa vurarak daima bağımsızlık hipotezinin reddedilmesine yol açmaktadır. Böylece, ANOVA testi sonuçları aylık brüt ücret ve meslek arasındaki bağımlılığı hemen her düzeyde doğrulamaktadırlar. Aynısı test koşulları doğrulanması için de geçerlidir ve varsayım doğrulaması genellikle ihmal edilir. Uygulamada sadece hangi mesleğin ele alındığına, $x$ faktörün çeşitli düzeylerinde tanımlanan bağımlı değişkenlerin değerler gruplarında uç değerlerin olup olmadığına, ve koşullu ortalamalara yakın olan değerlerin mi yoksa uzak olan değerlerin mi daha fazla olduğuna bakılmaktadır. Ayrıca, sıklıkla koşullu varyans benzeşmezliğin sezgisel değerlendirmesi yapılmaktadır. Bu diferansiyel küçük örneklemler ile çok büyük değilse, ve büyük örneklemler ile çok küçük ise, varyansların eşitliği varsayımı kabul edilebilir sayılır. Varyansların değerleri nedeniyle (x faktörü seviyesine bağlı) yüksek ücret düzeyi olan meslekler aynı zamanda yüksek mutlak ücret değişkenliği ile nitelendirilmektedir; bağımlılık yoğunluğu en çok ve en az kazandıran meslekler için ayrı ayrı ölçülmüştür.

Bağımlı değişkenin (gruplar arası değişkenliğin) koşullu ortalamalarda dalgalanması, bağımlı değişkenin bağımsız değişkene (x faktörü) bağımlılığının bir sonucu olarak kabul edilir. X faktörü (grup içi değişkenlik) düzeyince sabitlenmiş belirli meslek grupları içinde bağımlı değişkenin bireysel değerlerinin dalgalanması, bağımlı değişkenin diğer faktörlere bağımlılığının bir sonucu olarak kabul edilir. Bağımlı değişkenin x faktörüne bağımlılığı ne kadar güçlü ise, gruplar arası değişkenliğin oranı o kadar da büyük olur. Bu nedenle genel değişkenlikte grup içi değişkenlik oranı daha az olur.

Tablo 11 ve 12, incelenen döneminin her yılında en çok ve en az kazandıran mesleklerde bireysel gruplar içinde aylık brüt ücret değişkenliğinin (bireysel mesleklerin iç değişkenliği) grup değişkenliğinden 


\section{M.İ. YENILMEZ- M.H.DEMIR}

(belirli meslekler arasında olan) daha ağır bastığını göstermektedir. Toplam değişkenliğgin gruplar arası değişkenlik oranı en çok kazandıran mesleklerde $\%$ 29,70 ile \% 33,11 arasında, en az kazandıran mesleklerde ise \% 0,89 ile \% 1,69 arasında değişmektedir. Özellikle ikinci durumda, aylık brüt ücret ile çalışanın mesleği arasında bağımlılık oldukça zayıftır. En çok kazandıran meslekler için sonuçlar çok da kötü değildir. Ancak bu, uzmanlar ve teknik elemanlardan daha yüksek kazanan yönetici personelin ücretinde standart sapma değerlerinde dolayı biraz hafife alınmış olabilir, çünkü bireysel gruplar içinde bağımlı değişken değerlerinin değişkenliği (x faktörü düzeyince sabitlenmiş olan) sadece x dışındaki diğer faktörlere bağımlı değişkenin bağımlılığı sonucu değildir. $\mathrm{Bu}$ değişkenlik ayrıca, bağımlı değişkenin $\mathrm{x}$ faktörüne bağımlılı̆ğ ile kısmen açıklanabilir. Bu durumda bile \% 100 yakın tayin oranı değerleri, bağımlı değişkenin $\mathrm{x}$ faktörüne güçlü bağımlılığını göstermektedir. Ancak alt değerler, bu bağımlılığın daha güçlü olamayacağına işaret etmemektedir.

Tablo 11 ve 12, aynı zamanda toplam standart sapma ve toplam aritmetik ortalamanın bir yıl içindeki tüm örneklemi için hesaplanmasını (en çok ve en az kazandıran meslekler için ayrı ayrı) göstermektedir. Verilerin özellikleri nedeniyle sadece aralık frekans dağılımı şeklinde olanların var olması regresyon ve korelasyon analizi yöntemlerinin kullanılmasını mümkün kılmamıştır. Ancak tayin oranının düşük değerlerinden dolayı bu bir sorun teşkil etmemektedir. Zira o genel olarak bağımlılık yoğunluğunu ölçer ve böylece de bağımlı değişkenin bağımsız değişkene bağımlılı̆̆ının sıkılığı regresyon fonksiyonu kullanılarak saptandığında her zaman zayıf çıkıyor. Başka bir deyişle, katsayı değerleri veya belirli bir (doğrusal, ikinci dereceden, vs.) bağımlının yoğunluğuna işaret eden tayin endeksleri her zaman ilgili tayin oranı değerinden daha düşük çıkar. Gerçekte bu, bağımlı değişkenin gözlenen değerleri değişkenliğinin sadece çok küçük bir 
kısmının seçili regresyon fonksiyonu ile açıklanabildiği anlamına gelir.

Tablo 11. Çalışanın Mesleğine Aylık Brüt Ücretin Bağımlılığı - En Çok Kazandıran Meslekler

\begin{tabular}{|c|c|c|c|c|c|}
\hline Y1l & $\begin{array}{c}\text { Koşullu varyansların } \\
\text { aritmetik ortalaması } \\
\text { (grup içi değişkenlik) }\end{array}$ & $\begin{array}{c}\text { Varyansın koşullu } \\
\text { aritmetik ortalaması } \\
\text { (gruplararası } \\
\text { değişkenlik) }\end{array}$ & $\begin{array}{c}\text { Toplam } \\
\text { standart } \\
\text { sapma }\end{array}$ & $\begin{array}{c}\text { Toplam } \\
\text { aritmetik } \\
\text { ortalama }\end{array}$ & $\begin{array}{c}\text { Tayin oranı } \\
(\%)\end{array}$ \\
\hline 2011 & 165.211 .494 & 69.801 .432 & 15,330 & 34,819 & 29,70 \\
\hline 2012 & 181.739 .482 & 89.960 .941 & 16,483 & 35,364 & 33,11 \\
\hline 2013 & 177.428 .323 & 81.334 .780 & 16,086 & 35,705 & 31,43 \\
\hline 2014 & 182.457 .673 & 86.135 .406 & 16,389 & 36,487 & 32,07 \\
\hline
\end{tabular}

Tablo 12. Çalışanın Mesleğine Aylık Brüt Ücret Bağımlılığı - En Az Kazandıran Meslekler

\begin{tabular}{|l|c|c|r|r|r|}
\hline & $\begin{array}{c}\text { Koşullu } \\
\text { Varyansların } \\
\text { Aritmetik } \\
\text { Ortalaması (Grup İçi } \\
\text { Değişkenlik) }\end{array}$ & $\begin{array}{c}\text { Varyansın Koşullu } \\
\text { Aritmetik Ortalaması } \\
\text { (Gruplar Arası } \\
\text { Değişkenlik) }\end{array}$ & $\begin{array}{c}\text { Toplam } \\
\text { Standart } \\
\text { Sapma }\end{array}$ & $\begin{array}{c}\text { Toplam } \\
\text { Aritmetik } \\
\text { Ortalama }\end{array}$ & $\begin{array}{c}\text { Tayin } \\
\text { Oranı } \\
(\%)\end{array}$ \\
\hline 2011 & 62.549 .069 & 559,691 & 7,944 & 15,645 & 0,89 \\
\hline 2012 & 64.314 .148 & 1.066 .924 & 8,086 & 16,014 & 1,63 \\
\hline 2013 & 64.295 .971 & 1.069 .338 & 8,085 & 16,280 & 1,64 \\
\hline 2014 & 67.186 .437 & 1.152 .569 & 8,267 & 16,762 & 1,69 \\
\hline
\end{tabular}

\section{SONUÇ}

Günümüz Türkiye'sinde ücretler bu yıl itibariyle artmamaktadır. Ekonomik ve mali kriz onların artışını yavaşlatmış, hatta dondurmuştur. Aylık brüt ücret medyan'ının yıllık büyüme oranı 21 yy. başlangıcından beri neredeyse \% 5'in altına hiç inmemiştir. Yöneticiler açık arayla en yüksek ortalama ücretleri kazananlardır. 2014 yılında, onların ortalama aylık brüt ücreti neredeyse 12.000 † iken, ikinci sırada en çok kazananlar olan uzmanlar 10.000 daha az kazanmışlardır. İkinci ve üçüncü en çok 


\section{M.İ. YENILMEZ- M.H.DEMIR}

kazandıran meslekler arasındaki uçurum aşırı değildir: üçüncü sırada bulunan teknik elemanlar ve yardımcı uzmanların ortalama aylık brüt ücreti 5.000 daha azdır. Bu rakam yöneticilerin aldığı rakamdan iki kat düşüktür. Yöneticiler, ücretlerinde önemli bir değişkenlik göstermektedirler. Finans ve sigorta hizmetlerinde çalışanlar ortalama 120.000 t kazanırken, restoran yöneticileri sadece 45.015 kazanmaktadırlar. Öte yandan, en az kazandıran nitelik gerektirmeyen mesleklerde aylık ortalama brüt ücret 1.000 t çok az geçmiştir; mutlak ücret değişkenliği nispeten küçüktür; altgrupların bazıları yoksulluk sınırda yaşamaktadır. Ofislerde, otellerde ve diğer işyerlerinde temizlikçi ve yardımcıları olarak çalışanlar, örneğin, 2014 yılında ortalama brüt olarak sadece yaklaşık 1.200 kazanmıştır. Ücret düzeyi gelişimi açısından 2010 yılı Türkiye'de kritik bir yıl olmuştur.

2010 ve 2014 yılları arasındaki dönemde ücretler genel olarak hem en çok kazandıran mesleklerde, hem de en az kazandıran mesleklerde az da olsa büyüme göstermiş ve ortalama büyüme oranı yine olumlu bir trend yakalamıştır. Nitelik gerektirmeyen mesleklerde yöneticilerin yaklaşık \% 7'sinin ve işçilerin \% 82-87'sinin aylık brüt ücreti dönem boyunca 5.000 t denk veya düşük olmuştur. Buna rağmen, aylık brüt ücretin çalışanın mesleğine bağımlılı̆̆ının çok zayıf olduğu da doğrulanmıştır. Küresel olarak, ücretlerin gelişimi sadece GSYİH ile değil, bir dizi diğer faktörler ile de ilişkilidir. Ne çalışanlar (işgücü arz edenler), ne de işverenler (işgücü talep edenler) homojen gruplar oluşturmaktadır. İşü̈cü piyasasının her iki tarafında bulunan aktörlerinin çeşitli türleri ve çıkarları bulunmaktadır. Bunlar beraber maaş ve ücretlerin nihai düzeyini etkileyen çeşitli piyasa dışı faktörlerle (örneğin, sınırlı işgücü hareketliliği, yasama engelleri, sendikaların faaliyetleri, asgari ücret düzeyi, vs.) etkileşim içine girmektedirler. 


\section{KAYNAÇA}

ALANIZ, E., GINDLING, T. H., TERRELL, K. (2011). "The Impact of Minimum Wages on Wages, Work and Poverty in Nicaragua", IZA Discussion paper series, No. 5702: 1-47.

BALTAGI, B.H., BAŞKAYA, Y.S., HULAGU, T. (2011). "The Turkish Wage Curve: Evidence from the Household Labor Force Survey", Working Paper 1106: Research and Monetary Policy Department, Ankara: Central Bank of the Republic of Turkey.

BATTISTI, M., FELBERMAYR, G.J., PERI, G., POUTVAARA, P. (2014). "Immigration, Search, and Redistribution: A Quantitative Assessment of Native Welfare", NBER Working Paper No. w20131.

BRANUCKER, H., JAHN, E. (2011). "Migration and Wage-setting: Reassessing the Labor Market Effects of Migration", Scandinavian Journal of Economics, 113(2): 286-317.

CAI, H., CHEN, Y., ZHOU, L.A. (2010). "Income and Consumption Inequality in Urban China", Economic Development and Cultural Change, 58: 385-413.

DAGUM, C. (1997). "A Systematic Approach to the Generation of Income Distribution Models", Journal of Income Distribution, 6:105-126.

DEMİR, O. (2001). “Türkiye'de Kamu Açıkları ve Artış Sebepleri”, D.E.Ü. İIBB Dergisi, 16(2):11-30.

EUROSTAT(2015). Labour Market and Labour force survey (LFS) Statistics European Union Labour Force Survey - Annual Results 2015.

EVANGELISTA DE CARVALHO FILHO, I. (2012). "Household Income as a Determinant of Child Labor and School Enrollment in Brazil: Evidence from a Social Security Reform", Economic Development and Cultural Change, 60:399435 .

FIDRMUC, J., SENAJ, M. (2014). "Income, Schooling and Housing Wealth during Economic Reforms, Finance a úvěr”, 64: 160-176.

FIELDS, G.S. (2010). "Does Income Mobility Equalize Longer-term Incomes? New Measures of an Old Concept", Journal of Economic Inequality, 8: 409-427.

GHOSHEH, N. (2013). "Wage protection legislation in Africa", Conditions of Work and Employment Branch, Geneva: ILO. 


\section{M.İ. YENILLMEZ- M.H.DEMIR}

HASSAN, I. B., AZALİ, M., LEE, C. (2014). "Feldstein-Horioka Puzzle and International Capital Mobility in High Income Countries: A Pool Mean Group Approach", Engineering Economics, 25: 480-486.

HUSSMANNS, R. (2004). Defining and Measuring Informal Employment, Geneva: International Labour Office.

HUSSMANNS, R. (2005), "Measuring the informal economy: From Employment in the Informal Sector to Informal Employment", ILO Working paper, No. 53.

IMMERVOLL, H. (2007). "Minimum Wages, Minimum Labour Costs and the Tax Treatment of Low-Wage Employment”, IZA Discussion Paper, No. 2555.

NORDMAN, C.I., ROUBAUD F. (2009). "Reassessing the Gender Wage Gap in Madagascar: Does Labour Force Attachment Really Matter?", Economic Development and Cultural Change, 57(4): 785-808.

OECD (2010). OECD Economics Surveys: Turkey 2010, Paris: Organization for Economic Co-operation and Development.

OECD (2012). OECD Economics Surveys: Turkey 2011, Paris: Organization for Economic Co-operation and Development.

OECD (2015). OECD Economics Surveys: Turkey 2014, Paris: Organization for Economic Co-operation and Development.

ÖZCAN, Y. ÜÇDOĞRUK, Ş., ÖZCAN, K.M. (2003). "Wage Differences by Gender, Wage and Self-Employment in Urban Turkey", Journal of Economic Cooperation, 24(1): 1-24.

ÖZER, H. (2001). “Erzurum'da Hanehalklarının Tüketim Kalıplarının Yapısı ve Gelir Hipotezlerinin Analizi”, D.E.Ü. İ̈BF Dergisi, 16(1):35-46.

RIENER, G. (2012). "Inequality and Mobility of Household Incomes in Europe: Evidence from the EHCP", Applied Economics, 44:279-288.

SALEM, B., BENSIDOUN, I., PELEK, S. (2011). "Informal Employment in Turkey: An Overview", Région et Dévelopement, 34: 58-84.

TANSEL, A., DALGIC, B., GUVEN, A. (2014). "Wage Inequality and Wage Mobility in Turkey", IZA Discussion paper series, no. 8669:1-53. 
Dokuz Eylül Üniversitesi İktisadi ve İdari Bilimler Fakültesi Dergisi Cilt:32, Sayl:1, Yll:2017, ss. 243-269

Totty, E. (2015). "The Effect of Minimum Wages on Employment: A Factor Model Approach", IRLE Working Paper No. 110-15. http://irle.berkeley.edu/workingpapers/110-15.pdf

Turkish Statistical Institute (2011). Income and Living Conditions Survey Micro Data Set (2008-2010).

Turkish Statistical Institute (2012). Press Release on the Household Labor Force Survey for December 2011.

Turkish Statistical Institute (2015). Press Release on the Household Labor Force Survey for December 2014.

TURNER, J. R., THAYER, J. F. (2001). Introduction to Analysis of Variance. Thousand Oaks: Sage Publications.

UYGUÇ, N. (2003). "Cinsiyet, Bireysel Değerler ve Meslek Seçimi”, D.E.Ü. İİB Dergisi, 18(1):93-103.

World Bank (2014). Turkey Country Economic Memorandum (CEM) on Informality: Causes, Consequences and Policies, Washington D.C.: The World Bank. 